
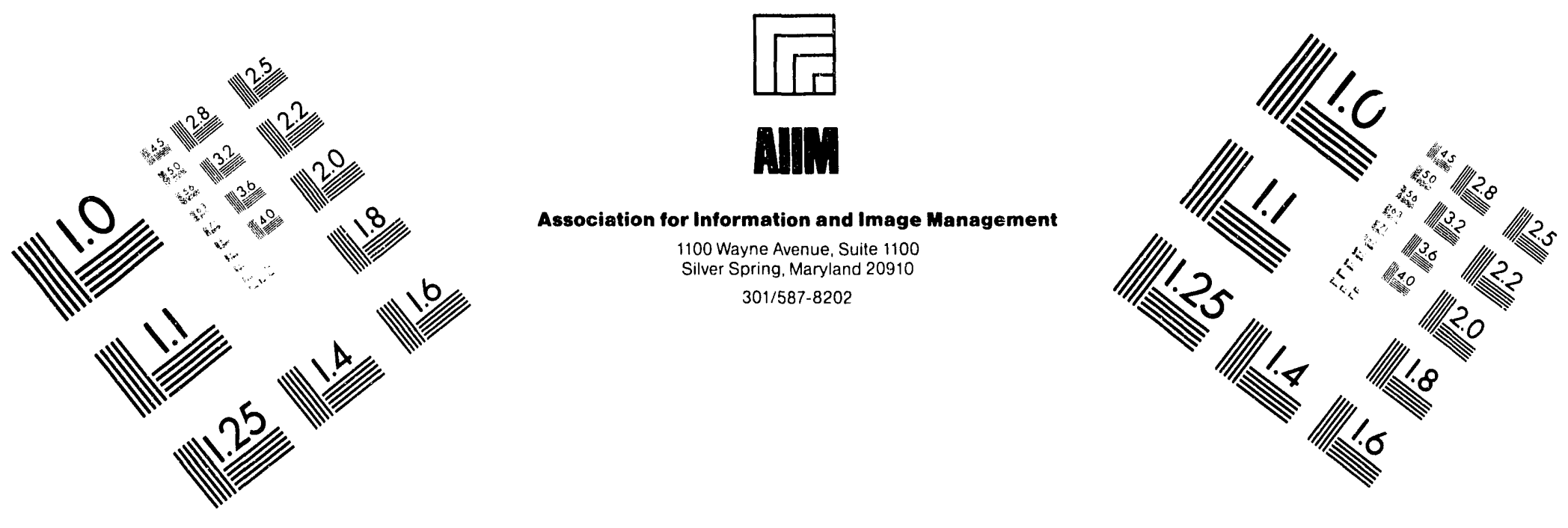

\title{
Centimeter
}

$\begin{array}{llllllllllllllll}1 & 2 & 3 & 4 & 5 & 6 & 7 & 8 & 9 & 10 & 11 & 12 & 13 & 14 & 15 & \mathrm{~mm}\end{array}$

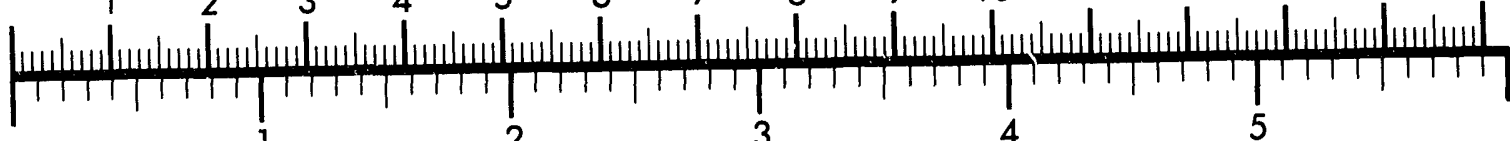
Inches
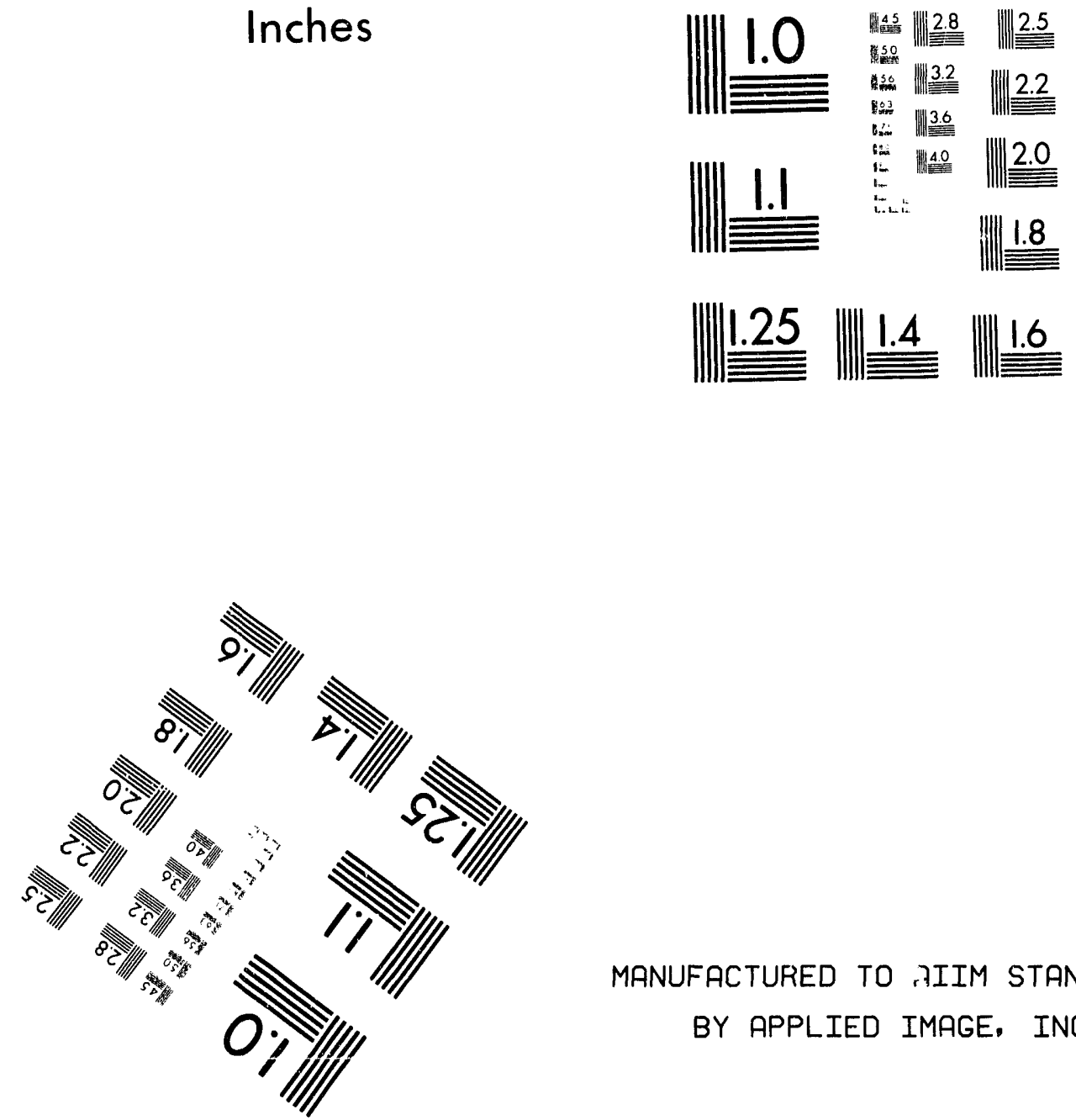

MANUFACTURED TO IIIM STANDARDS BY APPLIED IMAGE, INC.

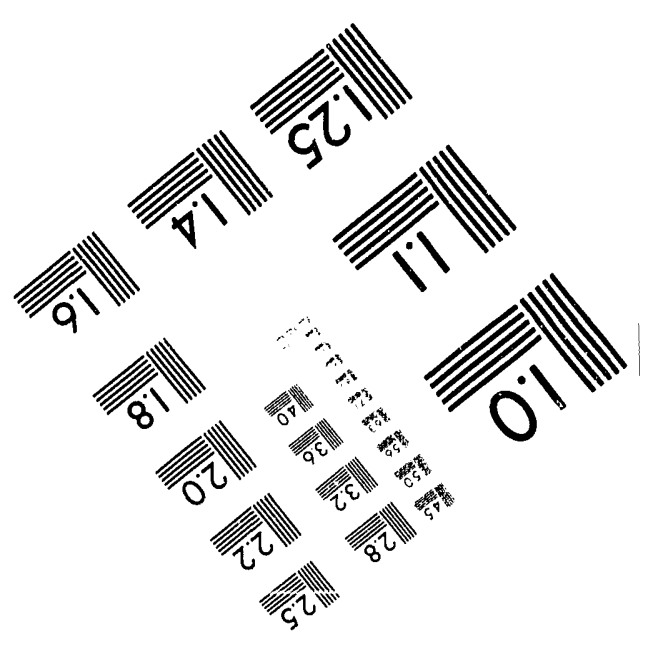



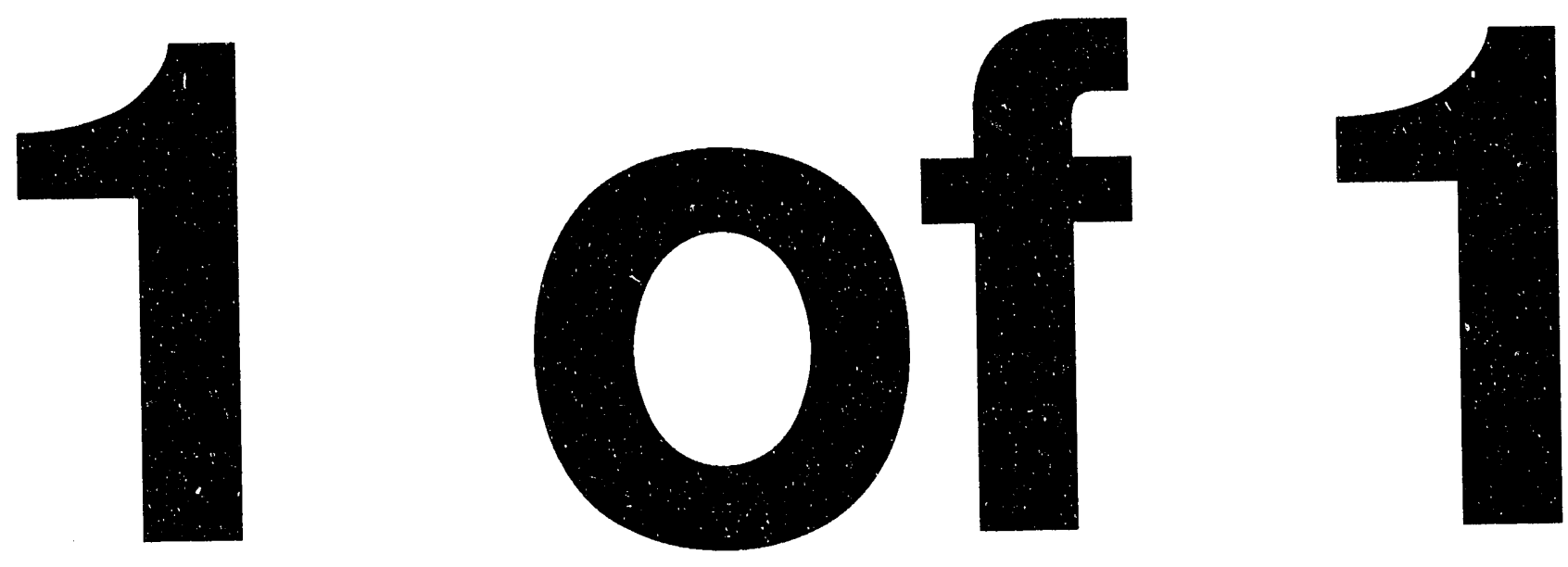


\title{
POE/CH/10324- T3
}

\section{An Examination of the}

\section{Hazardous Materials Transportation Uniform Safety Act (HMTUSA):}

\section{A. Southern Perspective}

\section{March 1992 \\ DISCLAIMER}

\begin{abstract}
This report was prepared as an account of work sponsored by an agency of the United States Government. Neither the United States Government nor any agency thereof, nor any of their employees, makes any warranty, express or implied, or assumes any legal liability or responsibility for the accuracy, completeness, or usefulness of any information, apparatus, product, or process disclosed, or represents that its use would not infringe privately owned rights. Reference herein to any specific commercial product, process, or service by trade name, trademark, manufacturer, or otherwise does not necessarily constitute or imply its endorsement, recommendation, or favoring by the United States Government or any agency thereof. The views and opinions of authors expressed herein do not necessarily state or reflect those of the United States Government or any agency thereof.
\end{abstract}

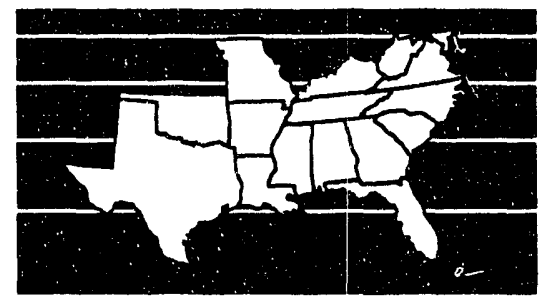

\section{Southern States Energy Board} 3091 Governors Lake Drive, Suite 400 Norcross, Georgia 30071

(404) 242-7712

FC01-87CH 10324

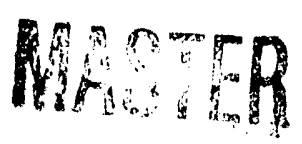




\section{Introduction}

On November 16, 1990, President Bush signed into law the most comprehensive amendments to the Hazardous Materials Transportation Act (HMTA) in 15 years. The Hazardous Materials Transportation Uniform Safety Act of 1990 (HMTUSA) was created by Congress in an effort to strengthen and clarify the HMTA. This paper will discuss the act's provisions as they affect shipments of spent fuel and high-level radioactive materials as well as the impact of those provisions on routing and emergency response issues in the southern region.

The roles played by states and localities in the regulation of hazardous materials transportation have grown considerably since the HMTA was passed in 1974. The act originally granted the Secretary of Transportation broad authority and specified that state and local requirements inconsistent with federal law and associated regulations should be preempted except under certain circumstances. The legislative history of the HMTA indicates that Congress intended to centralize state and local regulations concerning the transportation of hazardous waste.

Since the enactment of the HMTA, however, states and local governments have in fact enacted numerous laws concerning hazardous waste transportation. These laws are often state specific and, as a result, may conflict with other hazardous waste regulations produced by contiguous states or the federal government. The result is that shippers and carriers have to comply with multiple state and local registration, licensing, permitting, and shipping notification requirements. In some cases, one state's rules contradict another state's rules, making it difficult or impossible to determine which rule or rules take precedence. It is this lack of uniformity among state and local regulations that prompted the passage of HMTUSA.

Although much of HMTUSA is directed primarily at non-radioactive hazardous materials, several provisions of the ac. are limited solely to radioactive materials. These provisions include the initiation of a study on the safety of dedicated trains versus other trains for shipping spent fuel and high-level radioactive waste, the initiation of a mode and route selection study and the introduction of inspection requirements for motor vehicles before each shipment of highway 
route-controlled quantities of radioactive materials. Other provisions of HMTUSA may also indirectly affect radioactive materials, including emergency response planning and training and regulation of interstate dispute resolution processes.

HMTUSA consists of seven key provisions that affect radioactive materials: clarification of regulatory jurisdiction; highway routing standards; broadened industry registration; safety permits for motor carriers of high risk materials; expanded nuclear transportation requirements; new provisions for emergency response training and planning; and a public process for assessing the feasibility of a federally operated central reporting system and data center. In addition to amending various HMTA provisions, the new HMTUSA act provides appropriations to carry out the specific goals of the legislation. The act authorizes appropriations for the 1991, 1992 and 1993 fiscal years.

\section{HMTUSA Provisions Affecting Radioactive Materials}

\section{A. Preemption (Secs. 105(a) and 112)}

HMTUSA delineates three jurisdictional schemes: 1) areas of exclusive federal jurisdiction; 2) joint federal and state jurisdiction; and 3) matters open to state or local law or regulation under certain circumstances. State, tribal, or local government regulations that "concern" the following subjects are preempted unless they are "substantially the same" as the HMTA or its regulations:

- designation, description, and classification of hazardous materials;

- packing, repacking, handling, labeling, marking and placarding;

- shipping documents;

- written accident reporting; and

- design, manufacturing, repairing, testing, etc. of containers. 
The act also preempts any state or local law or regulation: 1) if compliance with both the state and federal law is impossible; or 2) if the state law is an obstacle to accomplishing the purposes of the HMTA.

HMTUSA leaves the issue of penalty assessment within the jurisdiction of state and local governments. The act provides that if any state, tribe or local government assesses a penalty for a violation of a regulation concerning hazardous waste, no other authority can assess a penalty for the same violation. Thus, localities may determine the amount and types of fines issued for a violation of HMTA regulations.

These provisions will most likely affect southern states in the area of hazardous materials classification. Although most states do not wish to alter federal definitions of hazardous materials, some states impose various regulations concerning subgroups of hazardous materials. For instance, a southern state may require additional precautionary or safety measures with respect to shipments of radioactive waste through the state. The question may arise whether a regulation of this type encroaches upon the federal right to define and classify hazardous materials. If such a regulation is found to encroach upon federal authority, HMTUSA mandates that federal law preempt the measure.

HMTUSA also contains provisions that bear directly on the federal versus state dispute resolution process. Under HMTUSA, once a party has filed for a Department of Transportation (DOT) inconsistency ruling, that party cannot bring an action in court on the same issue for six months or until DOT issues a ruling, whichever occurs first. After a decision has been rendered by DOT, then any party to the inconsistency ruling can appeal the decision to a federal court of proper jurisdiction.

While this process helps to streamline inconsistency rulings, several loopholes remain in the new law. First, a person may proceed directly to court and challenge a state law, thereby completely bypassing the DOT inconsistency process. Second, the six month prohibition applies only against the party who actually petitioned DOT for an inconsistency ruling. Any other party to the inconsistency ruling may proceed to court without regard to the DOT proceedings. 


\section{B. Highway Route Selection (Sec. 105(b))}

HMTUSA requires DOT to develop rules concerning the designation of routes for transporting hazardous materials. The act also authorizes DOT to hear and resolve interstate routing disputes. Although this portion of the act is aimed primarily at non-radioactive hazardous materials, it is foreseeable that some of the provisions on route selection may indirectly affect the transportation of radioactive materials. For instance, it is possible that DOT will amend its radioactive materials rules to incorporate aspects of the new interstate dispute resolution process.

Moreover, under HMTUSA, DOT will issue federal standards for designating and limiting highway routes for placarded shipments of hazardous materials. The states may then designate or limit routes pursuant to the federal guidelines. Also, local governments within each state can designate or limit routes only with the approval of their respective state government. This process will produce a more uniform system of route designation while simultaneously allowing state governments to designate the routes within their respective boundaries. The use of federal guidelines should reduce problems among and between states concerning interstate shipments of hazardous materials.

DOT's standards allow for public participation in the route selection process on issues such as traffic concerns, the availability of reasonable access, population density, type of highway exposure and delays in transportation and emergency response capabilities. State governments must designate routes that comply with all DOT guidelines. Compliance should create a uniform system of route designation and thereby reduce disputes among and between states concerning shipments of hazardous materials. However, if a state disagrees with actions taken by another state, the states may proceed through a dispute resolution process.

HMTUSA requires DOT to establish a dispute resolution process. Using that process, the department will resolve routing disagreements among and between states when and if states petition to enter into dispute resolution. Upon petition, DOT has a year to resolve the dispute. HMTUSA provides that the DOT decision should promote the greatest level of highway safety without unreasonably burdening commerce. The decision should also ensure compliance with the new 
federal standards. The act further provides that no judicial action may be brought until an administrative decision is issued or until one year after filing a petition. Any state can bring an action in court for review within three months after the decision is final.

Although much of HMTUSA is aimed at clarifying and unifying the route designation process, the act also provides a "grandfather clause" exempting certain state route designations from the new HMTUSA procedures. Existing route designations and those put into place prior to two years after the federal standards were issued will stand if they are consistent with the substance of the federal standards. Procedural compliance need not be demonstrated.

\section{Registration, Permits and Fees (Sec. 106(c) and (d) and 112(b))}

Mandatory registration filing is required for shippers and carriers transporting hazardous materials. HMTUSA provides for registration of shippers engaged in: shipping or transporting highway route-controlled quantities of radioactive materials; class A or B explosives; toxics by inhalation; bulk operations; and transporting any placarded quantity of hazardous materials over $5,000 \mathrm{lbs}$. Federal, state and local governments are exempt from this registration requirement. In addition to the mandatory registration requirement, DOT retains the right to require any other person to file a registration statement as well.

HMTUSA also establishes a safety permit program for motor carriers that transport any of five named commodities including: class A or B explosives; liquified natural gas; toxics by inhalation; and highway route-controlled quantities of radioactive materials. Although the act does not specifically set forth the standards for obtaining a permit, DOT permitting rules and regulations already in place probably will cover HMTUSA permits absent additional rules or regulations pursuant to the act. Under this new policy, shippers of hazardous materials will only be allowed to use permitted carriers.

Under HMTUSA, states retain authority to assess fees for transporting hazardous materials; however, the fees must be assessed for transportation purposes only. Fees collected for other purposes are impermissible. Fees must be equitably assessed and collected. 


\section{Funding for Emergency Response Planning and Training (Sec. 17)}

Within two years, DOT, in coordination with members of the National Response Team, will develop a curriculum of courses necessary to train public sector emergency response and preparedness teams. Section 17 calls for continued periodic dissemination of training courses. This program will be funded at $\$ 1$ million annually for fiscal years ' 91 and '92 from general revenues. Funding for the program during fiscal years '93-'98 will also be set at \$1 million annually and will be obtained from registrant fees supplied by hazardous waste shippers and carriers.

HMTUSA requires that all companies engaged in shipping, transporting and handling hazardous materials must provide training for their employees. Employees must receive instruction for safe handling, storing and transporting of hazardous materials. A Curriculum Committee will be formed by DOT and will be responsible for developing a standard training curriculum. The curriculum will include a recommended course of study for planning and response, and a list of recommended basic courses and minimum number of hours of training for planning and response. After it is formed, the Curriculum Committee will have two years to produce a standard curriculum.

Funding for the training programs will begin two years after passage of the act (i.e., fiscal year 1993). A planning grant program will be funded from the annual registration fees required by DOT beginning that same fiscal year. A total of $\$ 5$ million will be apportioned from the registration fees to fund the grant program. States will be eligible for a planning grant to develop emergency plans and to determine the need for regional response teams. At least 75 percent of the grant money must go to local emergency planning commissions. The federal government will provide 80 percent of the funds necessary to implement the program but the state must provide the remaining 20 percent. These grants will be allocated on an equal basis among qualified states.

A training grant program will also be funded from the annual registration fees at $\$ 7.8$ million per year. States will be eligible for the money to train public sector employees to respond to hazardous materials accidents. Once again, states must provide 20 percent of the necessary funding. These grants will he allocated on a needs basis. Also, in order to receive a training grant, the state's training program must be approved by DOT. 
In the past, southern states have expressed dissatisfaction with federal emergency response training programs owing to a paucity of course offerings as well as the failure to reach emergency response teams in rural areas. By focusing the grant programs more on localities than on the state governments themselves, HMTUSA may overcome this problem. Also, unlike many of the previous training courses, this training curriculum will focus on civilian emergency response in lieu of military or war-time emergencies.

HMTUSA requires federal agencies such as DOT, the U.S. Department of Energy (DOE), the U.S. Nuclear Regulatory Commission (NRC) and the Federal Emergency Management Agency (FEMA) to review their respective emergency response training programs and coordinate them to minimize duplication of effort and expense. These agencies, with the exception of the NRC, are required to provide technical assistance to states, tribes and local governments for emergency response training and planning. While there has been no official interpretation from any federal agency on how these training programs will be developed, in the past agencies, especially DOE, have developed training programs with input from state governments. For instance, DOE's training program for transuranic (TRU) waste transportation has been developed with input from states serving as corridors between the federal facilities that produce TRU waste and the department's storage facility, the Waste Isolation Pilot Plant (WIPP). DOE's Office of Civilian Radioactive Waste Management (OCRWM) is also involved in the initial planning stages of implementing Section 180(c) of the Nuclear Waste Policy Amendments Act (NWPAA), which requires OCRWM to provide technical assistance, training and funding for states affected by shipments of spent fuel and high-level radioactive waste.

\section{E. Federal Contractors (Sec. 120)}

The HMTUSA also contains provisions requiring federal contractors who transport hazardous materials or manufacture, fabricate, repair, etc., hazardous materials shipping containers to comply with federal, state, local and tribal laws to the same extent as any other person or organization that engages in those activities. 
The language of this portion of the act may require DOE carrier contractors to adhere to state and local laws and regulations. Such a requirement may present constitutional questions as to whether federal contractors can be regulated by state laws governing hazardous materials transportation, especially if those laws impact interstate commerce. The issue has not been brought before a court of competent jurisdiction for resolution to date.

In addition to the provisions calling for compliance with state laws and regulations, HMTUSA specifically requires federal contractors to comply with all "substantive and procedural" requirements of federal law. Since HMTUSA is relatively new and cases and regulations defining its provisions are scarce, it is unclear how some questions will be answered, e.g., when conflicts arise with respect to the laws and rules governing federal contractors.

\section{F. Placarding Requirements and Shipment Tracking (Sec. 25)}

According to Section 25, a rulemaking procedure will be initiated by DOT within 30 days of the passage of this act to improve the placarding system. DOT will consider issues relating to the placard coding system as well as concerns over the size and form of the placards themselves. In addition, DOT will coordinate with the National Academy of Sciences to study the feasibility and necessity of a central reporting system and a computerized telecommunications data center. A total of $\$ 350,000$ is authorized to be appropriated for the study. The Secretary of Transportation will review the placarding regulations as well as the study, and make recommendations to Congress on the subject. A computerized telecommunications system will not be implemented without congressional approval.

It is uncertain whether these provisions will affect future radioactive materials shipments; however, if DOT decides to change the character of the placarding system for hazardous materials, the radioactive placarding system could receive new codes as well as a new symbolic design for the placards themselves. It is less likely that changes in the computerized shipment reporting system for hazardous materials will affect spent fuel and high-level radioactive materials shipments, 
however. DOE has already selected the TRANSCOM computerized tracking system for WIPP shipments and it stands to reason that this system or a like system will be used for other radioactive shipments.

HMTUSA provisions covering railroads (Secs. 28, 30 and 116[a], [b] and [c]) hold that state hazardous materials rail inspections shall be governed by the system used in rail safety inspections. This section may have been created in an effort to limit states' abilities to enforce hazardous materials regulations against railroads. Congress has authorized $\$ 5$ million per fiscal year to pay for half the cost of inspectors.

The act further restricts state action in regulating railroads by providing that nothing in the HMTA or HMTUSA modifies the scope of the preemption provisions found in the Federal Railroad Safety Act (FRSA) of 1970. Under the FRSA, a state law related to any DOT-regulated area of "railroad safety" is preempted unless it is necessary to address a local safety hazard, it is not incompatible with any federal law and it does not place an undue burden on interstate commerce.

Under the provisions of the act, DOT must also conduct various studies concerning the present use of railroads for shipment of hazardous materials and possibilities for future use of the railways for radioactive waste and spent fuel. DOT is required to study the rail tank car design process and criteria, and issue a report and recommendations to Congress. This provision may have an indirect effect on the shipment of radioactive waste if other studies indicate that rail shipments will be a favorable mode of transporting waste. Moreover, the study could assist in the design and production of shipping cars for transporting spent fuel and other forms of radioactive waste. DOT also must study the safety of using dedicated trains for transporting high-level radioactive waste and spent fuel compared with the safety of using other methods of rail transportation. This section further requires DOT to amend regulations in accordance with the study findings.

In addition, HMTUSA requires DOT to study factors for shippers and carriers to consider in making modal and routing choices. DOT will have to assess the safety impacts of various factors, including population densities, infrastructure, emergency response capabilities, risk terrain, continuity of routes, availability of alternative routes and environmental impact. 


\section{HMTUSA's Effects on Southern States Routing and Emergency Response Section 180(c) Planning}

\section{A. HMTUSA's Effect on Routing Issues}

Conducting a state-by-state analysis of HMTUSA's anticipated impact on routing requirements indicates that most southern state officials are currently unfamiliar with HMTUSA provisions. Most of the officials contacted by the SSEB staff, however, indicated that their state is currently in compliance with federal laws and regulations such as the HMTA and HM-164. The fact that a state is in compliance with current federal routing regulations will aid that state in adhering to any future federal regulations with respect to radioactive waste shipments. At this time, however, HMTUSA's impact on routing is not understood by many state officials owing to the lack of information available to them on the act's provisions. This situation should change over time as officials are educated on HMTUSA's provisions.

One of the goals of the HMTUSA is to increase uniformity in state regulations concerning the routing of shipments of hazardous materials. Achieving this goal will allow for a safer and more efficient means of transporting and disposing of hazardous materials. The existence of a uniform system for routing hazardous materials may also aid in the future shipment of radioactive waste since a model uniform system of routing will already be established and can easily be attached and amended to the current laws governing radioactive waste. Thus the hazardous materials routing provisions of the HMTUSA may indirectly impact future provisions governing the shipment of radioactive waste.

\section{B. Section 180(c) Emergency Response Issues in Light of HMTUSA}

State officials were also uninformed about HMTUSA issues with respect to emergency response training. However, the great majority of southern state officials indicated that states could use additional emergency response training, especially at the local level. It would again be 
speculative to discuss the impact of HMTUSA on emergency response training required under the provisions of $\S 180$ (c) of the Nuclear Waste Policy Amendments Act (NWPAA), which require the U.S. Department of Energy to provide technical assistance, training and funding for states in preparing for shipments of spent fuel and high-level radioactive waste, since state officials do not know the specific details concerning DOE's plans for implementing $\$ 180(\mathrm{c})$ training. Also, the agencies involved with planning the training under HMTUSA are still in the initial phases of the planning process.

One major issue that will have to be decided in the future is how $\$ 180(\mathrm{c})$ and HMTUSA training will be administered to state and local governments. If there is overlap in the training courses developed under bothi programs, states may prefer to have the courses integrated into one training course. These issues are premature and will have to be addressed later. 


\section{LIST OF REFERENCES}

Harrison, Glen, Science Applications International Corporation. Letter to Mike Martinez of the Southern States Energy Board, Re: the Hazardous Materials Transportation Uniform Safety Act, August 23, 1991.

"President Bush Signs the Hazardous Materials Transportation Uniform Safety Act of 1990 (HMTUSA)." Hazardous Materials Transportation Safety Newsletter. U.S. Department of Transportation, Washington, D.C., Winter 1990.

Radiological Transportation Emergency Response Training Course Funding and Timing in the Southern States (Draft). The Southern States Energy Board, Norcross, Georgia, January 1991.

Southern Routes for High-level Radioactive Waste: Agencies, Contacts and Designations. The Southern States Energy Board, Norcross, Georgia, May 1991.

Staff Summary and Analysis of HMTUSA Provisions. The Western Interstate Energy Board, Denver, Colorado, March 1991. 

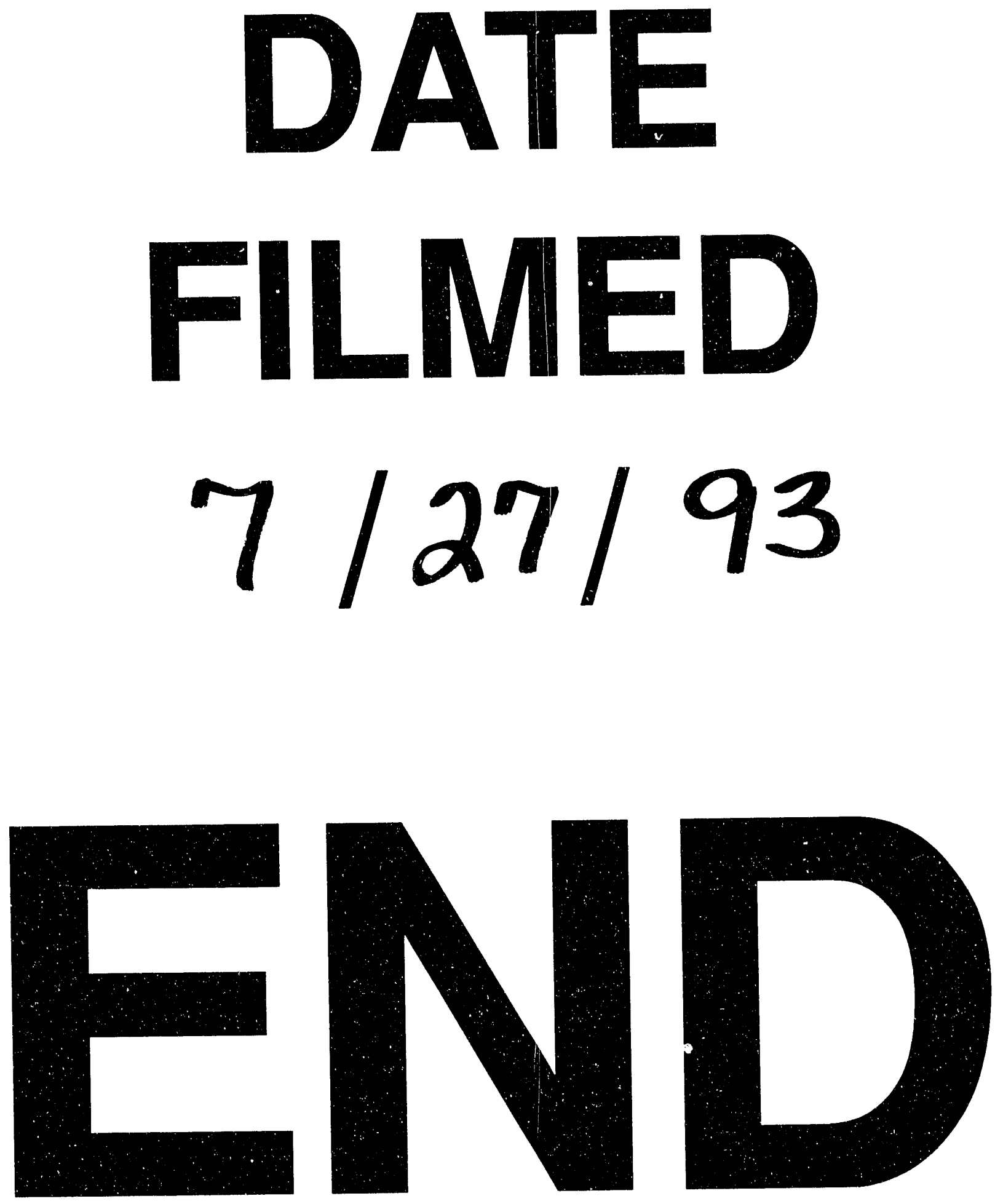
h. . 11, n

.

। 